\title{
ADRENOCORTICAL STEROID METABOLISM AND ADRENAL CORTICAL FUNCTION IN LIVER DISEASE
}

\author{
By RALPH E. PETERSON * \\ (From The National Institute of Arthritis and Metabolic Diseases, Bethesda, Md.)
}

(Submitted for publication July 27, 1959; accepted October 1, 1959)

Zondek (1) as early as 1934 demonstrated that enzymes of the liver destroyed the biological activity of the estrogens. Since then both in vivo and in vitro studies have provided much evidence to show that the liver is the organ primarily responsible for the catabolism of the steroid hormones: estrogens, androgens, progesterone, and the corticosteroids (2). However, not until the development of improved methods for measurement of certain of the adrenocortical steroids and their metabolites, and the availability of labeled radioactive cortisol, corticosterone, and aldosterone has it been possible accurately to evaluate the influence of liver disease on the rate of degradation and synthesis of the steroids in man. The studies here reported are based on the use of certain of these newer techniques.

On incubation with rat liver tissue, cortisol and cortisone are rapidly metabolized, but only very slowly with other tissues (3-5). Perfusion studies have demonstrated a very rapid metabolism of the steroids by the liver but not by other organs (6-8). Hechter, Frank, Caspi and Frank (9) found that the major portion of the cortisone and cortisol administered into the portal vein in dogs was not recovered as unaltered steroid from the hepatic venous blood. Bradlow, Dobriner and Gallagher (10) found that 70 per cent of a dose of tritium-labeled cortisone administered to mice was found in the liver within five minutes after intravenous administration. Administered cortisol also disappears rapidly from the circulation in rats (11), and this rapid metabolism can be prevented by hepatectomy but not by nephrectomy (12).

The liver in man has a high capacity for metabolizing the circulating blood cortisol, as demonstrated by the fact that the level of 17-hydroxycorticosteroids in the hepatic vein blood is lower than the level in the arterial blood $(13,14)$. Adrenocortical steroids administered intravenously

* Now at Cornell University Medical College, New York, N. Y. to man disappear rapidly from the blood $(15,16)$. Only minimal quantities are lost via the expired $\mathrm{CO}_{2}(17)$ or the biliary or gastrointestinal tract $(15,16)$. Also, practically all of the administered steroid is metabolized prior to its excretion in the urine $(15,16)$, and thus it is apparent that urinary excretion plays a relatively minor part in eliminating the biologically active steroid. Thus, metabolic transformation by the liver must play the predominant role in terminating the action of the steroids.

Because of the major role of the liver in the catabolism of the corticosteroids, it might be expected that this organ could indirectly influence the synthesis of corticosteroids by the adrenals. Many investigators have attempted to determine whether alterations in the functional capacity of the liver result in changes in adrenal cortical function. Until recently studies of adrenal cortical function in both acute and chronic liver disease were based on measurements of urinary steroids. There has been general agreement that the urinary 17-ketosteroids are low in various forms of liver disease -acute viral hepatitis (18-21), toxic hepatitis (20), portal cirrhosis (18-22), biliary cirrhosis $(23,24)$, and also in obstructive jaundice (18-21, 25). Urinary androgen excretion, as measured by bioassay, has also been found to be low in cirrhosis of the liver $(26,27)$. However, since only a small fraction ( 5 to 10 per cent) of the cortisol is metabolized to 17-ketosteroids (28), the urinary level of this material does not represent an adequate index of the functional capacity of the adrenal cortex to secrete corticosteroids such as cortisol. Furthermore, the rate of adrenal cortical secretion of 17 -ketosteroids may not always parallel the rate of secretion of adrenal corticosteroids.

Although urine levels of "corticoids" have been reported to be normal or elevated in acute hepatitis (21) and cirrhosis $(21,23,25,29-31)$, the data in these studies are difficult to interpret because of the nonspecific methods of assay used. Brown, 
Willardson, Samuels and Tyler (32), using a more reliable assay method, found the urinary corticoids to be low in cirrhosis. Plasma 17-hydroxycorticosteroid levels have been reported to be normal in cirrhosis of the liver $(33,34)$. In other studies of cortisol metabolism in liver disease, infused cortisol was reported to disappear from the plasma at a decreased rate in patients with hepatitis or cirrhosis of the liver $(15,32,33)$.

Studies of the adrenals in patients with cirrhosis of the liver coming to autopsy have demonstrated a decrease in lipoid material (35) and narrow and frequently nodular adrenal cortices (36).

\section{MATERIALS AND METHODS}

Fourteen patients with moderately severe cirrhosis of the liver, as judged by clinical signs and symptoms and liver function tests, and 3 patients with acute viral hepatitis, served as the subjects of this study. Those with cirrhosis of the liver had the classical symptoms, signs, and laboratory findings, viz. prolonged sulfobromophthalein retention, reversed albumin/globulin ratio with low serum albumin, elevated serum bilirubin, and abnormal thymol turbidity or cephalin flocculation tests. On clinical grounds, most of these patients were presumed to have alcoholic cirrhosis, and in the majority of the subjects the diagnosis of cirrhosis was confirmed by liver biopsy. One of the 3 patients with acute hepatitis had homologous serum (post-transfusion) hepatitis.

Plasma cortisol and urinary corticosteroids were determined by the modified (37) procedure of Silber and Porter (38) using phenylhydrazine and sulfuric acid. Urinary 17-ketosteroids were determined by the Zimmermann procedure, modified from the Holtorff and Koch method (39). Plasma corticosterone was determined by an isotope dilution method (40). Aldosterone excretion in the urine was determined by the double isotope derivative method $(41,42)$.

The steroids (100 to $200 \mathrm{mg}$ ) for intravenous administration were dissolved in ethanol and diluted to $300 \mathrm{ml}$ with 5 per cent dextrose in water to a final alcohol concentration of approximately 5 per cent. Following rapid ( 10 to 15 minutes) infusion of the steroids between 8 and 9 a.m., plasma samples were collected serially at 20 to 30 minute intervals for 2 to 3 hours and assayed. Plasma steroid concentration was plotted semilogarithmically against time, and the rate of disappearance of the steroids from the plasma expressed as a biologic halftime. The following plasma steroids were assayed by the phenylhydrazine method: cortisol, dihydrocortisone, dihydrocortisol, tetrahydrocortisone, tetrahydrocortisol, $9 \alpha$ fluorocortisol, $\Delta^{1} 9 \alpha$-fluorocortisol, and $\Delta^{1}$-cortisol.1 The

\footnotetext{
1 In this paper the trivial names of the steroids have been used. Cortisol $(11 \beta, 17 \alpha, 21$-trihydroxy-4-pregnene3, 20-dione). Cortisone (17 $\alpha, 21$-dihydroxy-4-pregnene-3, 11, 20-trione). Corticosterone (11 $\beta, 21$-dihydroxy-4-preg-
}

specificity of this assay method for each steroid was evaluated by isotope dilution (37). ${ }^{2}$ For each of these steroids, the isotope dilution assay indicated that at least 80 per cent of the steroid as measured by the phenylhydrazine assay represented the administered steroid.

The rate of disappearance of cortisol-4- $\mathrm{C}^{14}$ from the plasma and its rate of appearance in the ascitic fluid was determined by the double labeling technique using cortisol- $\mathrm{H}^{3}$ (42). The rate of disappearance of aldosterone from the plasma after infusion of aldosterone- $\mathrm{H}^{3}$ was determined by the double labeling technique using aldosterone and acetic-1- $\mathrm{C}^{14}$ anhydride (42).

Cortisone and corticosterone were determined by the isotope dilution method, since the phenylhydrazine assay for cortisone (43) and, to a lesser extent, the fluorometric assay for corticosterone (40) were not found to be specific for the determination of these steroids in plasma following their intravenous injection.

Urine cortisol concentration following the infusion of cortisol was determined by isotope dilution. Following the injection of cortisol-4- $\mathrm{C}^{14}$, the total radioactivity in the urine was determined by counting a small aliquot of the urine $(0.1$ to $0.5 \mathrm{ml})$ in an alcohol-toluene, DPO (diphenyloxyzol) and POPOP [1,4-bis-2-(5-phenyloxazolyl)-benzene] phosphor in the liquid scintillation spectrometer. The fractions of radioactive metabolites appearing as free and glucuronide conjugates were determined by previously described methods (15). The urine concentrations of tetrahydrocortisol following in-

nene-3, 20-dione). Aldosterone (11 $\beta, 21$-dihydroxy-4pregnene-3, 20-dione-18, al). Dihydrocortisone (17 $\alpha, 21-$ dihydroxy-pregnane-3, 11, 20-trione). Dihydrocortisol (11 $, 17 \alpha, 21$-trihydroxy-pregnane-3, 20-dione). Tetrahydrocortisone $(3 \alpha, 17 \alpha, 21$-trihydroxy-pregnane-11, 20-

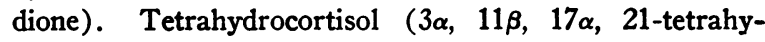
droxy-pregnane-20-one). Tetrahydrocorticosterone ( $3 \alpha$, $11 \beta, 21$-trihydroxy-pregnane-20-one). $9 \alpha$-Fluorocortisol (9 $\alpha$-fluoro-11 $\beta,-17 \alpha, 21$-trihydroxy-4-pregnene-3, 20-di-

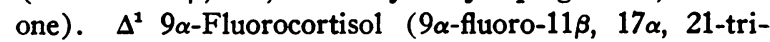
hydroxy-1,4-pregnene-3, 20-dione).

2 Cortisone-4-C ${ }^{14}$ (0.49 mc per mmole), cortisol-4-C $\mathrm{C}^{14}$ (1.47 mc per mmole), corticosterone-4- ${ }^{14}$ (1.47 mc per mmole), tetrahydrocortisone-4- $\mathrm{C}^{14}$ monoacetate $(0.4 \mathrm{mc}$ per mmole), and dihydrocortisone- $4-\mathrm{C}^{14}$ acetate $(0.4 \mathrm{mc}$ per mmole) were obtained from the Endocrine Study Section of the National Institutes of Health. The acetates were converted to the free steroids by hydrolysis with acetyl cholinesterase as described previously (43). $\mathrm{C}^{14}$ labeled tetrahydrocortisol and dihydrocortisol were prepared enzymatically (44) from cortisol-4-C ${ }^{14}$ (1.47 mc per mmole). Cortisol ( $0.11 \mu \mathrm{c}$ per $\mu \mathrm{g}), 9 \alpha$-fluorocortisol $(0.20 \mu \mathrm{c}$ per $\mu \mathrm{g}), \Delta^{1} 9 \alpha$-fluorocortisol $(0.05 \mu \mathrm{c}$ per $\mu \mathrm{g})$, $\Delta^{1}$ cortisol $(0.70 \mu \mathrm{c}$ per $\mu \mathrm{g})$, corticosterone $(1.5 \mu \mathrm{c}$ per $\mu \mathrm{g})$, and aldosterone $(1.5 \mu \mathrm{c}$ per $\mu \mathrm{g})$, were labeled with tritium by the Wilzbach (45) technique by a method previously described (42). All of the labeled steroids were purified by paper chromatography to a constant specific activity. All of the radioactivity measurements were made with the Packard liquid scintillation spectrometer. 
TABLE I

Plasma and urine steroid levels

\begin{tabular}{|c|c|c|c|c|c|c|}
\hline & \multirow[b]{2}{*}{ Age } & & \multicolumn{2}{|c|}{ Plasma steroids } & \multicolumn{2}{|c|}{ Urine steroids } \\
\hline & & & Cortisol & $\begin{array}{l}\text { Cortico- } \\
\text { sterone }\end{array}$ & Corticoids & $\begin{array}{l}\text { 17-Keto- } \\
\text { steroids }\end{array}$ \\
\hline & & & \multicolumn{2}{|c|}{$\mu g / 100 \mathrm{ml}$} & \multicolumn{2}{|c|}{$m g / d a y$} \\
\hline $\begin{array}{l}\text { E. M. } \sigma^{\pi} \\
\text { I. H. } \sigma^{\pi}\end{array}$ & $\begin{array}{l}38 \\
30\end{array}$ & $\begin{array}{l}\text { Cirrhosis } \\
\text { Cirrhosis }\end{array}$ & 17 & & & \\
\hline C. C. O" & 27 & Cirrhosis & 13 & & 0.9 & 9.1 \\
\hline D. R. & 52 & Cirrhosis & 12 & 0.4 & 2.8 & 0.5 \\
\hline T. T. o & 44 & Cirrhosis & 16 & 0.2 & 1.9 & 1.0 \\
\hline J.C. $\sigma^{7}$ & 60 & Cirrhosis & 15 & 0 & 2.4 & 2.0 \\
\hline J. M. $\sigma^{7}$ & 51 & Cirrhosis & 14 & & 4.0 & 1.9 \\
\hline M. B. & 35 & Cirrhosis & 21 & 0.8 & 3.0 & 1.5 \\
\hline E. W. $\sigma^{7}$ & 35 & Cirrhosis & 16 & 0.4 & 3.5 & 8.2 \\
\hline R. N. $\$$ & 52 & Cirrhosis & 9 & 0 & 4.5 & 2.0 \\
\hline A. C. $\sigma^{7}$ & 50 & Cirrhosis & 6 & 0.2 & 1.0 & 1.8 \\
\hline E. F. $\%$ & 60 & Cirrhosis & 13 & & 1.2 & 0.8 \\
\hline G. D. $\sigma^{7}$ & 50 & Hepatitis & 14 & & 3.6 & 5.5 \\
\hline C. C. & 24 & $\begin{array}{l}\text { Control* } \\
\text { Hepatitis }\end{array}$ & $\begin{array}{l}15 \\
13\end{array}$ & & $\begin{array}{l}4.9 \\
1.5\end{array}$ & 7.0 \\
\hline U. C. ₹ & & Control* & 18 & & $\begin{array}{l}1.5 \\
3.5\end{array}$ & 10.5 \\
\hline R. W. $\sigma^{7}$ & 27 & Hepatitis & 10 & & 4.4 & 11.0 \\
\hline Normals & & & $(90) \dagger$ & (20) & & \\
\hline Range & & & $6-25$ & $0.5-2.0$ & ᄋ 4-10 (20) & ㅇ 6-15 (18) \\
\hline \multirow[t]{2}{*}{ Mean, SD } & & & $13.5 \pm 3$ & $1.1 \pm 0.4$ & $6 \pm 1.2$ & $10 \pm 1.0$ \\
\hline & & & & & $\begin{array}{c}\sigma^{7} 4-14(36) \\
7 \pm 1.5\end{array}$ & $\begin{array}{c}\sigma^{7} 10-25(25) \\
15 \pm 1.5\end{array}$ \\
\hline
\end{tabular}

* Four to six months following recovery.

$\dagger$ Number of subjects ( ).

fusion of $200 \mathrm{mg}$ cortisol were determined by isotope dilution. Glucuronidase hydrolysis of the urine (15) was used in measuring the urine concentrations of radioactive steroid metabolites conjugated with glucuronic acid after the infusion of tetrahydrocortisone-4-C $\mathrm{C}^{14}$.

The size of the rapidly exchangeable miscible pool of cortisol and the rate of turnover of the pool were determined by the previously described method (46) using 0.2 to $0.3 \mathrm{mg}$ cortisol-4- $\mathrm{C}^{14}$ for intravenous injection. The pool size and rate of turnover of corticosterone were determined by the procedure used for cortisol, except that tritium-labeled corticosterone $(7$ to $30 \mu \mathrm{g})$ was used. In a few subjects the rates of turnover of cortisol, corticosterone, and aldosterone were measured by determining the dilution of injected labeled steroid by one or more of its urinary metabolites (47-49).

\section{RESULTS}

Table I lists the plasma cortisol and corticosterone levels, and the urine corticosteroid and 17ketosteroid levels in the patients with liver disease. Plasma cortisol was normal in all the subjects; however, plasma corticosterone levels were some- times found to be low or in the low normal range. ${ }^{3}$ The urinary corticosteroid and 17-ketosteroid concentrations were below normal in the great majority of the patients.

Cortisol (100 to $200 \mathrm{mg}$ ) was infused into eight patients with cirrhosis of the liver and into one patient with hepatitis, and in each subject the infused steroid disappeared from the plasma at a rate slower than normal (Table II). These findings agree with the results of a similar study of 12 patients with cirrhosis reported previously (15). In both cirrhotic and normal subjects, cortisol disappeared from the circulation more rapidly when infused in trace quantities than in pharmacologic (100 to $200 \mathrm{mg}$ ) quantities $(49,50)$. Figure 1 shows the results of studies carried out in a patient with cirrhosis and massive ascites (J.C.) given both a trace and a pharmacologic dose of

\footnotetext{
${ }^{3}$ In three patients with cirrhosis of the liver and ascites, maintained on a low salt diet, the plasma aldosterone level ranged from 0.08 to $0.15 \mu \mathrm{g}$ per cent (normal 0.03 to $0.08 \mu \mathrm{g}$ per cent).
} 
TABLE II

Biologic half-times of infused steroids (hours)

\begin{tabular}{|c|c|c|c|c|c|c|c|c|}
\hline & & $F^{*}$ & B & $\mathbf{E}$ & DHE & DHF & THE & THF \\
\hline $\begin{array}{ll}\text { T. T. } & \sigma^{7} \\
\text { D. R. } & \$ \\
\text { J. C. } & \sigma^{7} \\
\text { M. B. } & \$ \\
\text { J. M. } & \sigma^{7} \\
\text { R. N. } & \$ \\
\text { J. H. } & \sigma^{7} \\
\text { C. C. } & \sigma^{7} \\
\text { C. D. } & \sigma^{7}\end{array}$ & $\begin{array}{l}\text { Cirrhosis } \\
\text { Cirrhosis } \\
\text { Cirrhosis } \\
\text { Cirrhosis } \\
\text { Cirrhosis } \\
\text { Cirrhosis } \\
\text { Cirrhosis } \\
\text { Cirrhosis } \\
\text { Hepatitis } \\
\text { Control† }\end{array}$ & $\begin{array}{c}5.50 \\
3.08 \\
4.16 \\
5.00 \\
3.33 \\
3.16 \\
2.67 \\
10.3 \\
3.17 \\
2.17\end{array}$ & $\begin{array}{l}1.58 \\
1.72 \\
1.33 \\
1.83 \\
1.55 \\
1.40\end{array}$ & $\begin{array}{l}0.58 \\
0.67 \\
0.53 \\
0.50\end{array}$ & $\begin{array}{l}0.65 \\
0.50 \\
0.45\end{array}$ & $\begin{array}{l}0.75 \\
0.65 \\
0.45\end{array}$ & $\begin{array}{l}0.65 \\
0.65 \\
0.70 \\
0.60\end{array}$ & $\begin{array}{l}0.80 \\
0.75 \\
0.75 \\
0.55\end{array}$ \\
\hline Normals & & $(20) \ddagger$ & $(10)$ & $(12)$ & (4) & (4) & (7) & (7) \\
\hline Range & & $1.50-2.00$ & $1.16-1.50$ & $0.4-0.6$ & $0.5-0.8$ & $0.5-0.9$ & $0.5-0.9$ & $0.5-0.8$ \\
\hline Mean, SD & & $1.83 \pm 0.10$ & $1.33 \pm 0.05$ & $0.45 \pm 0.03$ & & & & \\
\hline * $\begin{aligned} \mathrm{F} & = \\
\mathrm{B} & = \\
\mathrm{E} & = \\
\text { DHE } & = \\
\text { DHF } & = \\
\text { THE } & = \\
\text { THF } & =\end{aligned}$ & $\begin{array}{l}\text { cortisol; } 20 \\
\text { corticoster } \\
\text { cortisone; } \\
\text { dihydrocor } \\
\text { dihydrocor } \\
\text { tetrahydro } \\
\text { tetrahydro }\end{array}$ & $\begin{array}{l}\text { infused. } \\
00 \mathrm{mg} \text { infuse } \\
\mathrm{g} \text { infused. } \\
; 100 \mathrm{mg} \text { inf } \\
100 \mathrm{mg} \text { infus } \\
\text { one ; } 100 \mathrm{mg} \\
\mathrm{ol} ; 100 \mathrm{mg} \text { in }\end{array}$ & $\begin{array}{l}\text { fused. } \\
\text { ised. } \\
\text { is. }\end{array}$ & $\begin{array}{l}\dagger \text { Six mon } \\
\ddagger \text { Number }\end{array}$ & $\begin{array}{l}\text { followin } \\
\text { subjects }\end{array}$ & ecovery. & & \\
\hline
\end{tabular}

cortisol-4- $\mathrm{C}^{14}$. It is apparent that even though the pharmacologic dose of cortisol-4-C ${ }^{14}$ disappeared from the plasma at a slower rate, there was a more rapid accumulation of a larger quantity of the labeled cortisol in the extravascular fluid (ascitic fluid). With a similar study in Patient T.T. with minimal ascites, infusion of a trace quantity $(0.2 \mathrm{mg})$ of labeled cortisol gave a biologic halftime of 3.0 hours whereas infusion of $200 \mathrm{mg}$ of labeled steroid gave a half-time of 5.5 hours.

Infused cortisone and corticosterone were metabolized at a rate only slightly slower than normal (Table II). The highly potent synthetic steroids, $9 \alpha$-fluorocortisol and $\Delta^{1} 9 \alpha$-fluorocortisol, were metabolized at a normal rate $\left(t_{1 / 2}=1.3\right.$ to 1.8 hours) in two patients (T.T. and C.C.) with cirrhosis, whereas $\Delta^{1}$-cortisol was metabolized at a rate slower $\left(t_{1 / 2}=5.8\right.$ hours, T.T.) than normal $\left(t_{1 / 2}=3.0\right.$ to 4.0 hours $)$.

Four of the major metabolites of cortisol (the dihydro and tetrahydro reduction products of cortisol and cortisone) were infused in doses of 100 mg. During the period of the study, endogenous plasma cortisol was reduced to zero by the prior administration of $2.5 \mathrm{mg}$ of $\Delta^{1} 9 \alpha$-fluorocortisol orally eight hours before the infusion of the steroids. All of these steroids were metabolized rapidly, and both the patients with cirrhosis and the normal subjects metabolized these four compounds at much the same rate (Table II).

In one patient with cirrhosis of the liver (T.T.), given tritium-labeled aldosterone, the labeled ster-

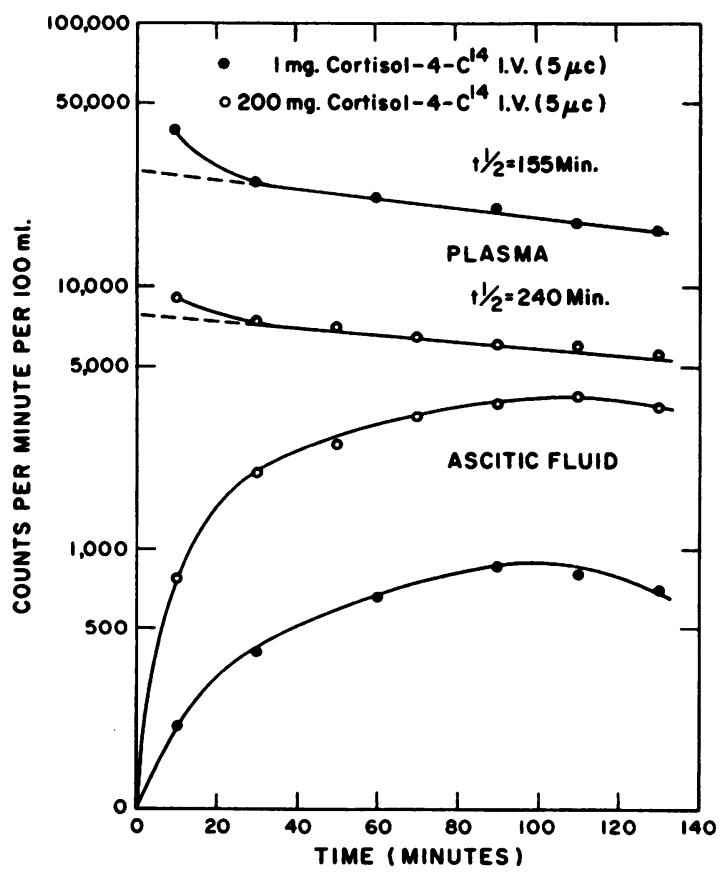

Fig. 1. Plasma and ascitic fluid levels of cortisol AFTER INTRAVENOUS ADMINISTRATION OF CORTISOL-4-C ${ }^{14}$. 
oid disappeared from the plasma at a rate only slightly slower $\left(t_{1 / 2}=70\right.$ minutes) than normal $\left(t_{1 / 2}=30\right.$ to 60 minutes) whereas in another patient with severe cirrhosis a half-time of 40 minutes was observed.

Table III lists the concentrations of cortisol in the urine following the infusion of $200 \mathrm{mg}$ cortisol to normal subjects and to patients with cirrhosis. A larger fraction of the infused cortisol appeared in the 24 hour urine in the cirrhotic. However, both the normal and the cirrhotic groups excreted the same fraction of the infused steroid as cortisol metabolites conjugated as glucuronides and giving the reaction with phenylhydrazine. Following the injection of tracer doses of cortisol4-C $\mathrm{C}^{14}$, the normal subjects and the patients with cirrhosis excreted essentially the same fraction of the injected steroid as free and as glucuronideconjugated metabolites. There was also no im-

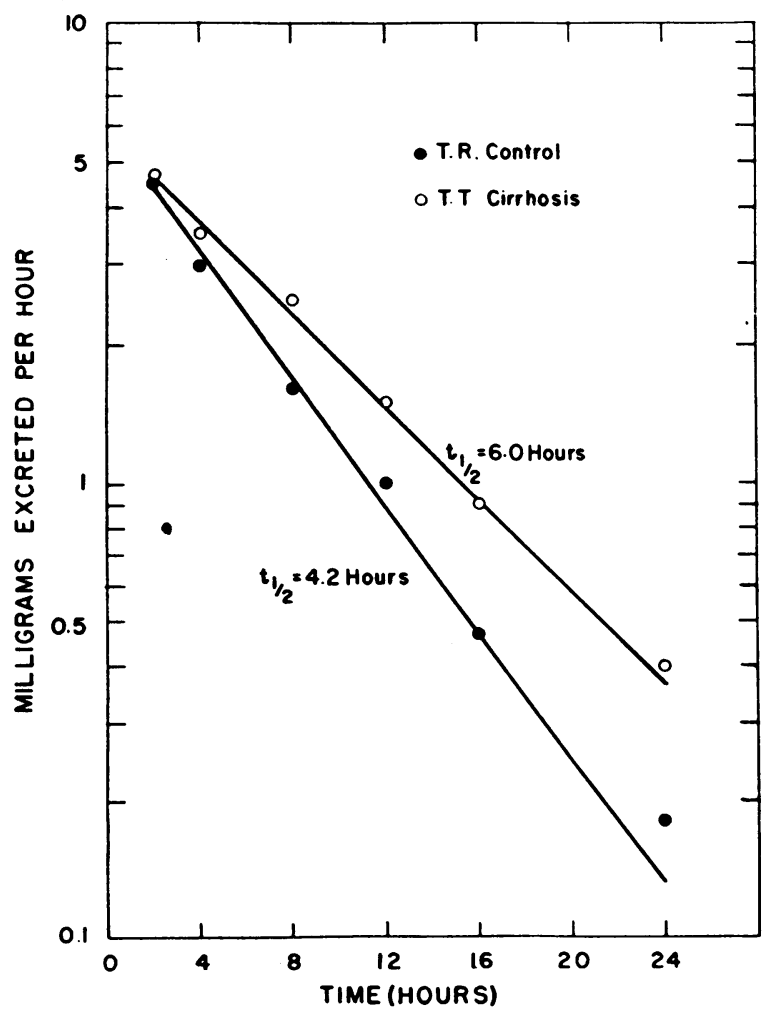

Fig. 2. URINARY EXCRETION OF TETRAHYDROCORTISOL FOLLOWING INFUSION OF 200 Mg CORTISOL. The tetrahydrocortisol measurements represent the tetrahydrocortisol present in the urine as a glucuronide conjugate. The assays were performed on urine fractions that had been previously extracted with dichloromethane to remove the unconjugated tetrahydrocortisol. portant difference in the fraction of the injected steroid radiometabolites excreted in the urine. A kinetic study of the appearance of a major glucuronide-conjugated metabolite of infused cortisol, tetrahydrocortisol, however, revealed that the metabolite appeared in the urine at a slower rate in the cirrhotic subject (Figure 2), although infused labeled tetrahydrocortisone appeared in the urine as glucuronide conjugates at a similar rate in the normal and in the cirrhotic (Figure 3). In Subject J.D., with familial nonhemolytic icterus, a condition known to be associated with a defect in the liver enzyme system necessary for the conjugation of many substances with glucuronic acid (51), the rate of appearance of the tetrahydrocortisone glucuronide was delayed (52).

Table IV gives the data on the miscible pool size and the rate of turnover of cortisol in six pa-

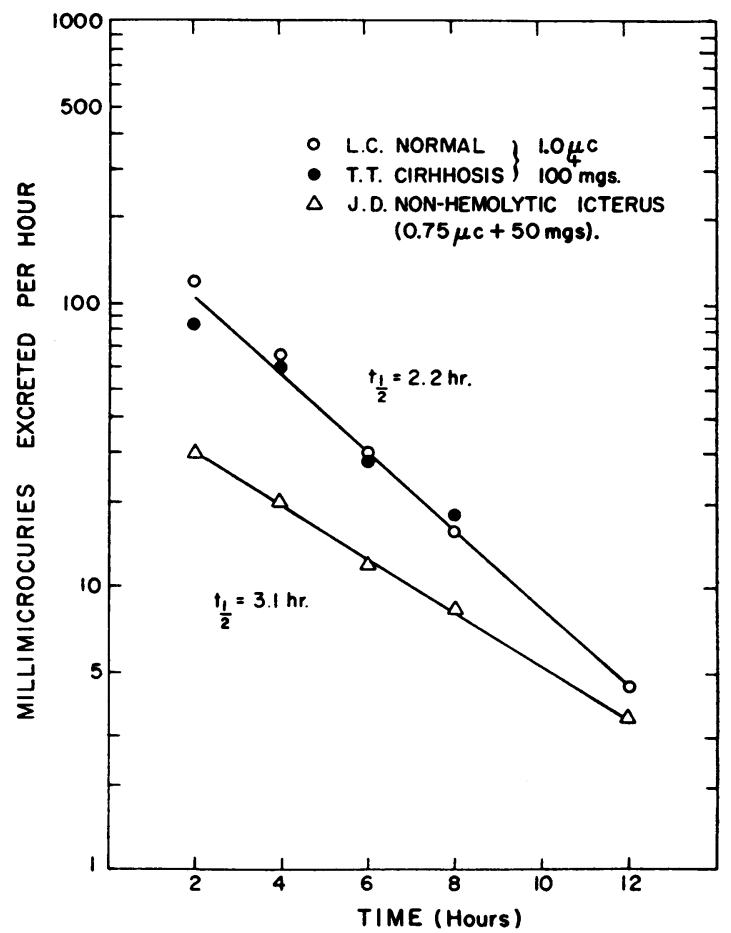

Fig. 3. URINARY EXCRETION OF RADIOACTIVE METABoLITES FOLLOWING INJECTION OF TETRAHYDROCORTISONE4- $\mathrm{C}^{14}$. The radioactive metabolites represent the labeled metabolites of tetrahydrocortisone present in the urine as glucuronide conjugates. The assays were performed on urine fractions that had been previously extracted with dichloromethane to remove the unconjugated steroids. In all three subjects the labeled free steroids represented less than 3.5 per cent of the administered tetrahydrocortisone-4- $\mathrm{C}^{14}$. 
tients with cirrhosis and in one patient with acute hepatitis. In the patient with acute hepatitis the studies were performed during the acute stage of the disease and again six months following recovery, and at a time when all of the liver function tests had returned to normal, although some hepatomegaly persisted. Patients J.M., M.B., and G.D. did not have ascites and Patients D.R., C.C., and T.T. had a moderate ascites. Patient J.C. was first studied at a time when he had marked ascites $(20$ to $30 \mathrm{~L})$ and one week after removal of $8.5 \mathrm{~L}$ of ascitic fluid. The removal of this volume of ascitic fluid did not alter the rate of turnover of cortisol.

It may be noted that the fraction of the pool replaced per hour was much decreased in the cirrhotics although the size of the miscible pool of cortisol was usually found to be slightly increased. When the turnover rate was calculated on the basis of the dilution of one of the major metabolites of the injected cortisol-4-C ${ }^{14}$, it was also shown that the rate of secretion of cortisol was markedly suppressed in cirrhosis. When expressed as the rate of secretion of cortisol per day (calculated as the product of the rate of turnover per hour $\times 24$ hours) these two methods of assay were not in agreement. This difference probably results from the fact that the rate studies cover only a three hour period of the day ( 9 a.m. to noon), when the
TABLE III

Urinary cortisol and metabolites of cortisol*

\begin{tabular}{|c|c|c|c|c|c|}
\hline & \multicolumn{3}{|c|}{$0.2-0.5 \mathrm{mg} \mathrm{C} 14$ cortisol (F) iv } & \multicolumn{2}{|c|}{$200 \mathrm{mg} \mathrm{F} \mathrm{iv}$} \\
\hline & \multirow{2}{*}{$\begin{array}{c}\% \\
\text { Excreted } \\
\text { total }\end{array}$} & \multicolumn{2}{|c|}{$\%$ Total excreted } & \multirow[b]{2}{*}{$\mathbf{F}$} & \multirow{2}{*}{$\begin{array}{l}\text { PNH† } \\
\text { glucu- } \\
\text { ronides }\end{array}$} \\
\hline & & Free & $\begin{array}{l}\text { Glucu- } \\
\text { ronide }\end{array}$ & & \\
\hline $\begin{array}{l}\text { T. T. } \\
\text { D. R. } \\
\text { M. G. } \\
\text { J. C. }\end{array}$ & $\begin{array}{l}80 \\
76 \\
82 \\
70\end{array}$ & $\begin{array}{l}4.0 \\
4.5 \\
6.0 \\
3.3\end{array}$ & $\begin{array}{l}50 \\
45 \\
60 \\
50\end{array}$ & $\begin{array}{l}m g \\
5.0 \\
5.6 \\
6.0 \\
5.0\end{array}$ & $\begin{array}{l}40 \\
46 \\
48 \\
38\end{array}$ \\
\hline & mals $(8)$ & & & Normals (5) & $(8)$ \\
\hline & $74-85$ & $3.8-5.5$ & $50-64$ & $2.5-3.8$ & $40-64$ \\
\hline
\end{tabular}

* These percentages represent the excretion of steroids during the 24 hour period following their administration. $\dagger \mathrm{PNH}=$ phenylhydrazine-reacting steroids.

rate of secretion of cortisol is known to be near maximal and probably greater in magnitude than the average secretion rate $(46,49)$.

A repeat turnover rate study was carried out in one patient (T.T.) during the 10 to 14 hour period following the continuous intravenous infusion of 4 units of corticotropin per hour. The plasma cortisol level in this patient rose rapidly to a level of $48 \mu \mathrm{g}$ per cent six hours following the start of the infusion and remained at this level during the subsequent 18 hours. The pool of cortisol was elevated, but the rate of synthesis of cortisol was

TABLE IV

Miscible pool and rate of turnover of cortisol in liver disease

\begin{tabular}{|c|c|c|c|c|c|c|}
\hline & & Pool & $\mathrm{t}_{3}^{*}$ & $\mathrm{kt}$ & Turnov & rate \\
\hline 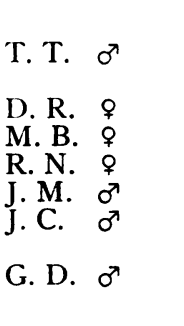 & $\begin{array}{l}\text { Cirrhosis } \\
\text { Cirrhosis, ACTH } \\
\text { Cirrhosis } \\
\text { Cirrhosis } \\
\text { Cirrhosis } \\
\text { Cirrhosis } \\
\text { Cirrhosis, ascites } \\
\text { Cirrhosis, post-ascites } \\
\text { Hepatitis } \\
\text { Control }\end{array}$ & $\begin{array}{r}m g \\
1.9 \\
13.6 \\
3.6 \\
2.5 \\
2.0 \\
1.5 \\
3.5 \\
3.3 \\
1.7 \\
1.5\end{array}$ & $\begin{array}{l}h r \\
6.90 \\
5.00 \\
8.60 \\
6.30 \\
1.78 \\
2.57 \\
4.10 \\
4.60 \\
2.77 \\
1.61\end{array}$ & $\begin{array}{c}\text { pools/hr } \\
0.10 \\
0.14 \\
0.08 \\
0.11 \\
0.39 \\
0.27 \\
0.17 \\
0.15 \\
0.25 \\
0.43\end{array}$ & $\begin{array}{l}m g / h r \ddagger \\
0.19 \\
1.90 \\
0.29 \\
0.27 \\
0.78 \\
0.41 \\
0.59 \\
0.49 \\
0.42 \\
0.65\end{array}$ & $\begin{array}{c}m g / d a y \S \\
1.9 \\
55 \\
4.0 \\
4.0 \\
9.0\end{array}$ \\
\hline $\begin{array}{l}\text { Normals (14) } \\
\text { Range }\end{array}$ & & $1.1-2.4$ & $1.0-2.3$ & $0.3-0.7$ & $0.7-1.2$ & $8-20$ \\
\hline Mean, SD & & $1.7 \pm 0.2$ & $1.4 \pm 0.2$ & $0.5 \pm 0.1$ & $0.85 \pm 0.08$ & $14 \pm 1.5$ \\
\hline
\end{tabular}

* Time for specific activity of plasma cortisol to be reduced by 50 per cent.

$\dagger$ Fraction of pool replaced per hour.

$\mp$ Calculated from the kinetic method of assay of change in specific activity of plasma cortisol after injection of 200 to $300 \mu \mathrm{g}$ of cortisol-4-C 14 . $4-\mathrm{C}^{14}$

$\$$ Calculated from specific activity of tetrahydrocortisone in 24 hour urine collected after 200 to $300 \mu \mathrm{g}$ of cortisol- 
TABLE V

Miscible pool and rate of turnover of corticosterone in liver disease

\begin{tabular}{|c|c|c|c|c|c|c|}
\hline & & Pool & $t_{1}$ & $\mathrm{k}$ & \multicolumn{2}{|c|}{ Turnover rate } \\
\hline $\begin{array}{l}\text { T. T. } \\
\text { D. R. } \\
\text { M. B. }\end{array}$ & $\begin{array}{l}\text { Cirrhosis } \\
\text { Cirrhosis } \\
\text { Cirrhosis }\end{array}$ & $\begin{array}{c}m g \\
0.18 \\
0.30 \\
0.11\end{array}$ & $\begin{array}{c}h r \\
1.54 \\
2.10 \\
1.10\end{array}$ & $\begin{array}{c}\text { pools } / h r \\
0.45 \\
0.33 \\
0.63\end{array}$ & $\begin{array}{c}m g / h r * \\
0.08 \\
0.10 \\
0.07\end{array}$ & $\begin{array}{c}m g / d a y \dagger \\
0.6 \\
1.0 \\
0.3\end{array}$ \\
\hline \multicolumn{2}{|c|}{$\begin{array}{l}\text { Normals (11) } \\
\text { Range }\end{array}$} & $0.2-0.4$ & $0.8-1.5$ & $0.4-0.9$ & $0.12-0.22$ & $1.5-4.0$ \\
\hline \multicolumn{2}{|c|}{ Mean, SD } & $0.3 \pm 0.04$ & $1.1 \pm 0.1$ & $0.6 \pm 0.1$ & $0.15 \pm 0.02$ & $2.1 \pm 0.2$ \\
\hline
\end{tabular}

* Calculated from the kinetic method of assay of change in specific activity of plasma corticosterone after injection of 7 to $30 \mu \mathrm{g}$ of corticosterone- $\mathrm{H}^{3}$.

$\dagger$ Calculated from specific activity of tetrahydrocorticosterone in 24 hour urine collected after 7 to $30 \mu \mathrm{g}$ of corticosterone- $\mathrm{H}^{3}$.

less than that observed in normal subjects after the continuous corticotropin infusion $(46,49)$.

Table $\mathrm{V}$ shows the data on the miscible pool size and turnover rate of corticosterone in three patients with cirrhosis.

\section{DISCUSSION}

The importance of the liver in the regulation and control of the level of circulating steroid becomes apparent when it is realized that the intensity of action of the hormone must be under continuous dynamic control. This rapid control is possible because of mechanisms within the liver that act to interrupt, by chemical attack, the biologic action of the hormone. Such enzymatic processes, that serve to terminate or to diminish the action of the steroid through conversion to inactive products, may be subject to alteration by diseases, especially those affecting the liver.

Previously, many of the conclusions regarding adrenal function in liver disease were drawn from studies of the urinary 17-ketosteroids which were usually found to be low. The patients in the present series were also found to have low urinary 17-ketosteroids. Adrenal function has also been evaluated on the basis of studies of urinary corticosteroids; however, in many instances rather nonspecific assay methods were used. Frequently the assay procedures did not utilize a hydrolytic procedure. Acidification of the urine to $\mathrm{pH} 1$ (53) does not hydrolyze the metabolites of cortisol (15). Since less than one per cent of the total quantity of cortisol or corticosterone synthesized per day is excreted in the urine $(15,54)$, it is not possible to measure adrenal cortical function by measuring the urinary cortisol or corticosterone concentration. Furthermore, the urine cortisol and corticosterone levels are essentially a reflection of the plasma level and may not be a good index of the rate of secretion of these steroids.

A urine steroid assay procedure capable of measuring all of the metabolites of cortisol would, of course, serve as a good quantitative assay of adrenal cortical function; however, since the urinary metabolites of the steroids are so numerous, any measurement of a single metabolite or group of metabolites may not represent a reliable index of adrenal secretion rate. A slight change in the pattern of the steroid metabolites may alter any interpretations of secretion rates. The phenylhydrazine colorimetric assay procedures after glucuronidase hydrolysis measure only 20 to 30 per cent of the total metabolites of cortisol, approximately one-half of the steroid metabolites that are conjugated with glucuronic acid $(15,55)$. Such an assay, however, may serve as an index of the relative state of activity of the adrenal cortex.

The results obtained in this study and the studies of Brown and associates (32), who used similar methods for assay of urinary corticosteroids, demonstrated that the urinary metabolites of cortisol were below normal. These investigators (32) also found that patients with liver disease and normal subjects excreted the same quantity of an infused dose of cortisol as phenylhydrazine-reacting steroid metabolites conjugated with glucuronic acid (Table III). If patients with liver disease and normal subjects excreted a comparable frac- 
tion of endogenously synthesized cortisol as phenylhydrazine-reacting metabolites, then a low urine corticosteroid level in patients with cirrhosis might suggest that adrenal cortisol secretion would be decreased. The data on urine corticoid concentration (Table I) and rate of synthesis of endogenous cortisol (milligrams per day, Table IV) might appear to be inconsistent with the data presented in Table III (e.g., in Patient T.T., both the urine corticoid level and cortisol turnover were $1.9 \mathrm{mg}$ per day). The poor specificity of the urine corticoid assay in this patient probably accounts for the fact that these two figures are identical (see also Patients D.R. and M.B.). In normal subjects with normal urine corticoid levels the urine corticoids usually account for 30 to 50 per cent of the total daily corticoid production (49).

In all of the subjects with liver disease, the plasma cortisol level was within the normal (8:00 a.m. range). The specificity of this determination was evaluated both in patients with hepatitis and with cirrhosis by the previously described isotope dilution method. This evaluation indicated that 80 to 95 per cent of the material measured with the phenylhydrazine steroid assay method was cortisol. Plasma corticosterone levels were slightly lower than normal, or at the lower limit of normal. The presence of a normal concentration of cortisol in the plasma indicates that the patients with liver disease had no deficiency of circulating cortisol. A normal level of cortisol can, however, be maintained in the plasma by either a decreased rate of catabolism of cortisol and an associated decreased rate of synthesis, or by an increased synthesis and an increased metabolism of the steroid. Thus, a normal plasma steroid level establishes that cortisol is being synthesized, but fails to indicate its rate of synthesis.

Differences in fraction of bound and unbound cortisol (56-59) may occur in liver disease. Recently it has been reported that some patients with liver disease may have an increased fraction of unbound cortisol, yet the total concentration of plasma cortisol (bound plus unbound) may be normal (60). Sandberg and Slaunwhite (61) however, recently reported that the transcortin binding of cortisol was normal in 16 patients with cirrhosis.

All of the patients with liver disease showed a decreased rate of clearance (metabolism) of in- fused cortisol from the plasma. This defect in the capacity of the liver to metabolize cortisol was quite specific since other naturally occurring steroids were metabolized at a rate close to normal. This was true for the biologically active corticosterone and cortisone, the biologically active synthetic $9 \alpha$-fluorocortisol and $\Delta^{1} 9 \alpha$-fluorocortisol, and the biologically inactive steroids $20 \alpha$ - and $20 \beta$-cortisol (15), dihydrocortisone, dihydrocortisol, tetrahydrocortisone, and tetrahydrocortisol. The rate of metabolism of aldosterone also did not appear to be markedly impaired.

When infused rapidly in quantities in the range of $100 \mathrm{mg}$, most steroids disappeared at rates approximately proportional to their concentration in peripheral blood plasma. If the steroid is distributed within the plasma and body tissues and if there is a state approximating equilibrium between plasma and the body tissues, the plasma concentration may be expressed as a simple exponential function of time. For comparisons of steroids with respect to their rate of metabolism or for purposes of comparing the rates of metabolism of steroids in different diseases, it is convenient to apply the term "biologic half-life" to this exponential process; i.e., the time at which half of any given quantity remains in the plasma. After the rapid infusion of a trace (microgram) quantity of the steroids cortisol or corticosterone, the biologic half-life was shorter despite the fact that, with both the microgram and milligram doses, the decline in plasma concentration represented a first order process. These differences in rate of disappearance of steroid from the plasma may result from the fact that equilibration between plasma and tissues is not approximated, and the plasma concentration may be expressed not as a single exponential but rather as a series of exponential terms in which the exponents are functions of the rate constants for chemical transformation within the liver, diffusion of the steroid from the plasma into the tissues, and re-entry of the steroid from the tissues into the plasma. A larger fraction of nonprotein-bound steroid available for diffusion into the tissues and re-entry into the plasma following the infusion of pharmacologic doses of steroid might be expected to alter the relative contributions of these various first order processes. That this may be so is suggested from the fact that with the larger doses of cortisol and corticosterone, a 
three- to fivefold larger volume of distribution was obtained $(15,16,46,50)$. The more rapid entry of labeled steroid into the ascitic fluid in the cirrhotic demonstrated that the body tissues and the extravascular fluid take up a larger fraction of the infused steroid when it is given in therapeutic quantities. The data from the studies of the plasma protein binding of these two steroids also lend support to this concept. With the trace dose, close to 100 per cent is protein-bound, whereas with larger doses only 70 to 80 per cent is protein-bound (56-59).

The great difference in the rate of metabolism of cortisol in the normal subject and the cirrhotic, as contrasted to the rather unimportant differences in the metabolism of other infused steroids, implies that the slower rate of metabolism of cortisol was not the result of impaired circulation through the liver, as has been suggested for the mechanism of the delayed removal of sulfobromophthalein (32). Because of the selective nature of the defect in cortisol metabolism it would seem unlikely that a deficiency of a cofactor such as reduced TPN could be involved, since TPNH is required for the metabolism of most of the steroids. It seems more reasonable to propose a defect in the enzyme system (44) for transforming cortisol to dihydrocortisol ( $5 \alpha$ - or $5 \beta$-dihydrocortisol dehydrogenase). This represents one of the predominant initial steps in the chemical inactivation of cortisol and would appear to be the enzyme system most likely involved. Dihydrocortisol was metabolized to tetrahydrocortisol at a normal rate. This presumes that the transformation of cortisol to dihydrocortisol is a major pathway for the metabolism of cortisol. It is not known if the enzymatic defect involves the soluble $5 \beta$ or the particulate $5 \alpha$ dehydrogenase; however. there is evidence that both of these enzymes have a high degree of substrate specificity (62).

More than one-half of the metabolites of cortisol have the reduced A ring; however, only about one-half of these are present as C-20-keto and approximately one-half appear in the urine as the C-20 reduced compounds (55). Thus, it is possible that there may also be a defect in the C-20 reductase enzyme system.

The normal rate of disappearance of infused tetrahydrocortisol from the plasma demonstrated that in cirrhosis of the liver there is no markedly impaired capacity of the liver to conjugate the steroid metabolites. Also, Patient T.T. with cirrhosis, excreted phenylhydrazine-reacting steroid glucuronide metabolites (Figure 3 ) at the same rate and in the same quantity as the normal subjects. The patient with congenital nonhemolytic jaundice, with the defective hepatic enzyme system for the conversion of bilirubin to its glucuronide conjugate, showed no defect in his capacity to metabolize infused cortisol (52); however, the rate of steroid glucuronide formation was reduced after administration of a loading dose of one of the tetrahydro metabolites of cortisol.

The slower rate of metabolism of cortisol in the subjects with cirrhosis undoubtedly accounted for a larger quantity of the infused cortisol in the urine because the plasma concentration was maintained at elevated levels for a longer time.

The results of the turnover rate studies utilizing cortisol-4-C ${ }^{14}$ are consistent with the plasma and urine steroid assay data and the studies of the rate of metabolism of infused steroids. The miscible pools of cortisol and corticosterone were normal or only slightly increased. The figures for the miscible pool size, however, probably represent only the rapidly turned over and rapidly exchangeable miscible pool. In the patients with ascites, the infused cortisol-4-C ${ }^{14}$ did not mix rapidly with the cortisol in the ascitic fluid.

The patients with liver disease synthesized cortisol and corticosterone at a decreased rate, and excreted a smaller quantity of metabolites of endogenous cortisol. These patients thus had adrenal cortical insufficiency in terms of quantity of cortisol synthesized; however, they were essentially "eucorticoid" in terms of a plasma cortisol level maintained in the normal range by virtue of a defect in the capacity of the liver to metabolize the circulating cortisol at the normal rate.

The primary defect in cirrhosis may be a decreased rate of hepatic enzymatic transformation of the circulating cortisol (cortisol $\rightarrow$ dihydrocortisol) with the consequent alterations in plasma cortisol resulting from this disturbance. On the basis of the mechanism of the negative feedback control of adrenocortical secretion, changes in the plasma cortisol produce opposite changes in the rate of secretion of the adrenocorticosteroids (63). Thus, if the rate of inactivation of cortisol is diminished, the increment in plasma cortisol will inhibit cortico- 
tropin secretion, and the resultant depression of adrenal cortisol synthesis will serve to maintain a normal concentration of plasma cortisol. Urquhart, Yates and Herbst (64) have shown a primary diminution of hepatic capacity for adrenocortical steroid inactivation in the rat after surgical removal of more than one-half of the liver. Following partial hepatectomy secondary adrenal atrophy occurred. The liver has also been presumed to play an important role in the regulation of adrenal cortical activity in thyroid disease (65).

If the urinary 17 -ketosteroid content is a reasonably reliable index of the production of 17 ketosteroids by the adrenal cortex, then the data from this and other studies would seem to indicate that adrenal 17-ketosteroid production as well as cortisol and corticosterone secretion are depressed. The low urine 17-ketosteroid levels are probably not the result of a decreased conversion of corticosteroid to 17-ketosteroids since normally the 17-ketosteroid metabolites of cortisol make up less than 10 per cent of the cortisol metabolites, and thus only a small fraction of the total urine 17 ketosteroids $(28,66)$.

Whereas adrenal glucocorticoid (cortisol and corticosterone) and adrenal androgen (17-ketosteroids) secretion are frequently suppressed in liver disease, mineralocorticoid (aldosterone) production appears not to be decreased. Urine aldosterone levels are known to be either normal or increased in hepatic cirrhosis (67-69). In patients with ascites, the urine aldosterone levels are usually markedly elevated; however, in patients without ascites, normal levels are usually found. The urine aldosterone concentration, like the urine corticoid level, may not always adequately reflect the secretory activity of the adrenal cortices, since the usual assay procedure for urinary aldosterone measures less than 5 per cent of the secreted steroid (41). Turnover rate studies on six patients with cirrhosis maintained on 200 to $500 \mathrm{mg}$ sodium diets yielded markedly elevated rates of secretion of aldosterone-500 to $3,000 \mu \mathrm{g}$ per day (41). 4 In all subjects urine aldosterone levels were also elevated; however, the increase in aldosterone secretion was usually proportionally greater than the

\footnotetext{
4 In six normal ambulatory subjects on an ad lib. sodium intake aldosterone secretion rates ranged from 150 to $400 \mu \mathrm{g}$ per day.
}

increase in the urinary aldosterone level. In a recent report of a case of cirrhosis, the aldosterone secretion rate was found to be 1,500 to $2,000 \mu \mathrm{g}$ per day and did not appear to be influenced by changes in sodium intake (70). Also, unlike cortisol metabolism, these changes in aldosterone metabolism were not associated with a striking change in its rate of metabolism.

\section{SUMMARY}

Plasma cortisol and corticosterone levels were normal in patients with liver disease; however, urine corticoids and 17-ketosteroids were usually below the normal level. Cortisol was metabolized at a diminished rate in the cirrhotics; however, most other infused steroids were metabolized at a normal rate. This defect in the metabolism of cortisol was discussed in terms of a low hepatic activity of the specific TPNH-dependent enzyme catalyzing the reduction of the 4,5 double bond. No impaired conjugation of the tetrahydrosteroid metabolites of cortisol was demonstrated. The rate of synthesis of cortisol and corticosterone was markedly reduced in the patients with cirrhosis. The rate of synthesis of aldosterone was increased in patients with cirrhosis maintained on a low sodium intake. Patients with cirrhosis have a relative adrenal insufficiency in the secretion of cortisol and corticosterone although under basal conditions they maintain a normal plasma cortisol level because they metabolize cortisol at a slower rate. These data suggest that there is a homeostatic mechanism mediated through the liverpituitary-adrenals which results in a decreased synthesis of cortisol and corticosterone in patients with liver disease in whom the rate of removal of cortisol by the liver is impaired.

\section{ACKNOWLEDGMENT}

We are indebted to Dr. Rudi Schmid for permission to study Patient J.D., with familial nonhemolytic icterus. We are also indebted to the Upjohn, Merck, and Schering pharmaceutical companies for generous supplies of steroids.

\section{REFERENCES}

1. Zondek, B. Über das Schicksal des Follikelhormons (Follikulin) im Organismus. Skand. Arch. Physiol. 1934, 70, 133.

2. Samuels, L. T., and West, C. D. The intermediary metabolism of the non-benzenoid steroid hormones. Vitam. and Horm. 1952, 10, 251. 
3. Schneider, J. J., and Horstmann, P. M. Effects of incubating Compound $\mathrm{E}$ and related steroids with various surviving rat tissues. J. biol. Chem. 1952, 196, 629.

4. Louchart, J., and Jailer, J. W. Inactivation of 11dehydro-17-hydroxycorticosterone by tissue slices. Proc. Soc. exp. Biol. (N. Y.) 1952, 79, 393.

5. Berliner, D. L., Grosser, B. I., and Dougherty, T. F. The metabolism of cortisol in eviscerated rats. Arch. Biochem. 1958, 77, 81.

6. Robbins, E. D., Burton, S. D., Byers, S. O., Friedman, M., St. George, S., and Ishida, T. Hydrocortisone metabolism in the perfused isolated rat liver. J. clin. Endocr. 1957, 17, 111.

7. Miller, L. L., and Axelrod, L. R. Cortisone metabolism in the perfused normal and experimental cirrhotic rat liver. Metabolism 1954, 3, 438.

8. Caspi, E., and Hechter, O. Corticosteroid metabolism in liver. IV. Isolation of certain cortisol-4-C $\mathrm{C}^{14}$ metabolites. Arch. Biochem. 1956, 61, 299.

9. Hechter, O., Frank, E., Caspi, E., and Frank, H. Corticosteroid metabolism in liver: In vivo metabolism of cortisone and cortisol by dog liver. Endocrinology 1957, 60, 705.

10. Bradlow, H. L., Dobriner, K., and Gallagher, T. F. The fate of cortisone- $T$ in mice. Endocrinology 1954, 54, 343.

11. Ulrich, F., and Long, C. N. H. Effect of stress on serum $\mathrm{C}^{14}$ levels in rats following administration of hydrocortisone-4-C $\mathrm{C}^{14}$ and corticosterone-4-C $\mathrm{C}^{14}$. Endocrinology 1956, 59, 170.

12. Tomizawa, H. H., Narahara, H. T., Gibbons, C. A., and Williams, R. H. A metabolic study of hydrocortisone in rats. Proc. Soc. exp. Biol. (N. Y.) 1954, 85, 51.

13. Nelson, D. H., Samuels, L. T., Williardson, D. G., and Tyler, F. H. The levels of 17-hydroxycorticosteroids in peripheral blood of human subjects. J. clin. Endocr. 1951, 11, 1021.

14. Plager, J. E., Samuels, L. T., Ballard, A., Tyler, F. $\mathrm{H}$., and Hecht, H. H. The rate of metabolism of cortisol in a normal human man. J. clin. Endocr. 1957, 17, 1.

15. Peterson, R. E., Wyngaarden, J. B., Guerra, S. L., Brodie, B. B., and Bunim, J. J. The physiological disposition and metabolic fate of hydrocortisone in man. J. clin. Invest. 1955, 34, 1779.

16. Migeon, C. J., Sandberg, A. A., Decker, H. A., Smith, D. F., Paul, A. C., and Samuels, L. T. Metabolism of 4-C ${ }^{14}$-cortisol in man: Body distribution and rates of conjugation. J. clin. Endocr. 1956, 16, 1137.

17. Hellman, L., Bradlow, H. L., Adesman, J., Fukushima, D. K., Kulp, J. L., and Gallagher, T. F. The fate of hydrocortisone-4-C ${ }^{14}$ in man. J. clin. Invest. 1954, 33, 1106.

18. Fraser, R. W., Forbes, A. P., Albright, F., Sulkowitch, H., and Reifenstein, E. C., Jr. Colorimetric assay of 17 -ketosteroids in urine. J. clin. Endocr. 1941, 1, 234.
19. Gilder, H., and Hoagland, C. L. Urinary excretion of estrogens and 17-ketosteroids in young, adult males with infectious hepatitis. Proc. Soc. exp. Biol. (N. Y.) 1946, 61, 62.

20. Eisenberg, H. L., Kirshen, M. M., Atlas, D. H., and Gaberman, P. 17-Ketosteroid excretion in liver disease. Gastroenterology 1951, 18, 36.

21. Peterson, R. E., Guerra, S., and Sborov, V. M. Steroid excretion patterns in acute viral hepatitis, with and without adrenocorticotrophin infusion. J. Lab. clin. Med. 1954, 43, 58.

22 Dohan, F. C., Richardson, E. M., Bluemle, L. W., Jr., and György, P. Hormone excretion in liver disease. J. clin. Invest. 1952, 31, 481.

23. Bongiovanni, A. M., and Eisenmenger, W. J. Adrenal cortical metabolism in chronic liver disease. J. clin. Endocr. 1951, 11, 152.

24. Ahrens, E. H., Payne, M. A., Kunkel, H. G., Eisenmenger, W. J., and Blondheim, S. H. Primary biliary cirrhosis. Medicine (Baltimore) 1950, 29, 299.

25. Sprague, R. G., Mason, H. L., and Power, M. H. Physiologic effects of cortisone and ACTH in man. Recent Progr. Hormone Res. 1951, 6, 315.

26. Zarrow, M. X., Munson, P. L., and Salter, W. T. A comparison of androgens determined biologically and 17 -ketosteroids determined chemically in urine (normal and abnormal). J. clin. Endocr. 1950, 10, 692.

27. Glass, S. J., Edmondson, H. A., and Soll, S. N. Sex hormone changes associated with liver disease. Endocrinology 1940, 27, 749.

28. Sandberg, A. A., Chang, E., and Slaunwhite, W. R., Jr. Conversion of 4-C ${ }^{14}$-cortisol to $C^{14}$-17-ketosteroids. J. clin. Endocr. 1957, 17, 437.

29. Shadaksharappa, K., Calloway, N. O., Kyle, R. H., and Keeton, R. W. Excretion of steroidal substances by the adrenal cortex in various diseases. J. clin. Endocr. 1951, 11, 1383.

30. Goldman, R., and Bassett, S. H. Diurnal variation in the urinary excretion of neutral lipid-soluble reducing steroids in congestive cardiac failure and cirrhosis of the liver with ascites. J. clin. Invest. 1952, 31, 253.

31. Schedl, H. P., Ditto, K., and Bean, W. B. Corticosteroid excretion in liver disease. J. Lab. clin. Med. 1953, 42, 116.

32. Brown, H., Willardson, D. G., Samuels, L. T., and Tyler, F. H. 17-Hydroxycorticosteroid metabolism in liver disease. J. clin. Invest. 1954, 33, 1524.

33. Englert, E., Jr., Brown, H., Wallach, S., and Simons, E. L. Metabolism of free and conjugated 17-hydroxycorticosteroids in subjects with liver disease. J. clin. Endocr. 1957, 17, 1395.

34. Wallace, E. Z., Christy, N. P., and Jailer, J. W. Clinical application of the simplified Silber-Porter method for determining plasma 17-hydroxycorticosteroids. J. clin. Endocr. 1955, 15, 1073.

35. Lloyd, C. W., and Williams, R. H. Endocrine 
changes associated with Laennec's cirrhosis of the liver. Amer. J. Med. 1948, 4, 315.

36. Barr, R. W., and Sommers, S. C. Endocrine abnormalities accompanying hepatic cirrhosis and hepatoma. J. clin. Endocr. 1957, 17, 1017.

37. Peterson, R. E., Karrer, A., and Guerra, S. L. Evaluation of the Silber-Porter procedure for determination of plasma hydrocortisone. Analyt. Chem. 1957, 29, 144.

38. Silber, R. H., and Porter, C. C. The determination of 17,21-dihydroxy-20-ketosteroids in urine and plasma. J. biol. Chem. 1954, 210, 923.

39. Holtorff, A. F., and Koch, F. C. The colorimetric estimation of 17-ketosteroids and their application to urine extracts. J. biol. Chem. 1940, 135, 377.

40. Peterson, R. E. The identification of corticosterone in human plasma and its assay by isotope dilution. J. biol. Chem. 1957, 225, 25.

41. Kliman, B. and Peterson, R. E. Unpublished observations.

42. Peterson, R. E. The application of tritium to the assay of steroids in biological extracts in Proc. of the Symposium on Advances in Tracer Applications of Tritium. Boston, New England Nuclear Corp. 1959 , p. 16.

43. Peterson, R. E., Pierce, C. E., Wyngaarden, J. B., Bunim, J. J., and Brodie, B. B. The physiological disposition and metabolic fate of cortisone in man. J. clin. Invest. 1957, 36, 1301.

44. Tomkins, G. M. Enzymatic mechanisms of hormone metabolism. I. Oxidation-reduction of the steroid nucleus. Recent Progr. Hormone Res. 1956, 12, 125.

45. Wilzbach, K. E. Tritium-labeling by exposure of organic compounds to tritium gas. J. Amer. chem. Soc. 1957, 79, 1013.

46. Peterson, R. E., and Wyngaarden, J. B. The miscible pool and turnover rate of hydrocortisone in man. J. clin. Invest. 1956, 35, 552.

47. Pearlman, W. H. [16 $-\mathrm{H}]$ Progesterone metabolism in advanced pregnancy and oophorectomized-hysterectomized women. Biochem. J. 1957, 67, 1.

48. Cope, C. L., and Black, E. The production rate of cortisol in man. Brit. med. J. 1958, 1, 1020.

49. Peterson, R. E. The miscible pool and turnover rate of adrenocortical steroids in man. Recent Progr. Hormone Res. 1959, 15, 231.

50. Samuels, L. T., Brown, H., Eik-Nes, K., Tyler, F. H., and Dominguez, O. V. Extra-adrenal factors affecting the levels of 17-hydroxycorticosteroids in plasma. Ciba Found. Coll. Endocr. 1957, 11, 208.

51. Schmid, R. Some aspects of bile pigment metabolism. Clin. Chem. 1957, 3, 394.

52. Peterson, R. E., and Schmid, R. A clinical syndrome associated with a defect in steroid glucuronide formation. J. clin. Endocr. 1957, 17, 485.

53. Klein, R., Papadatos, C., Fortunato, J., Byers, C., and Puntereri, A. Serum corticoids in liver disease. J. clin. Endocr. 1955, 15, 943.

54. Ayres, P. J., Garrod, O., Simpson, S. A., and Tait, J. F. A method for the determination of aldo- sterone, cortisol, and corticosterone in biological extracts, particularly applied to human urine. Biochem. J. 1957, 65, 639.

55. Fukushima, D. K., Leeds, N. S., Bradlow, H. L., Kritchevsky, T. H., Stokem, M. B., and Gallagher, T. F. The characterization of four new metabolites of adrenocortical hormones. J. biol. Chem. 1955, 212, 449.

56. Sandberg, A. A., Slaunwhite, W. R., Jr., and Antoniades, H. N. The binding of steroids and steroid conjugates to human plasma proteins. Recent Progr. Hormone Res. 1957, 13, 209.

57. Daughaday, W. H. Binding of corticosteroids by plasma protein. III. The binding of corticosteroids and related hormones by plasma and plasma protein fraction as measured by equilibrium dialysis. J. clin. Invest. 1958, 37, 511.

58. Bush, I. E. The physiochemical state of cortisol in blood. Ciba Found. Coll. Endocr. 1957, 11, 263.

59. Slaunwhite, W. R., and Sandberg, A. A. Transcortin: A corticosteroid-binding protein of plasma. J. clin. Invest. 1959, 38, 384.

60. Daughaday, W. H. Binding of corticosteroids by plasma proteins. Arch. intern. Med. 1958, 101, 286.

61. Sandberg, A. A., and Slaunwhite, W. R. Transcortin: A corticosteroid-binding protein of plasma. II. Levels in various conditions and the effects of estrogens. J. clin. Invest. 1959, 38, 1290.

62. McGuire, J. S., and Tomkins, G. M. The multiplicity and specificity of $\Delta^{4}-3$-ketosteroid hydrogenases (5a). Arch. Biochem. 1959, 82, 476.

63. Sayers, G., and Sayers, M. A. The pituitary-adrenal system. Recent Progr. Hormone Res. 1948, $2,81$.

64. Urquhart, J., Yates, F. E., and Herbst, A. L. Hepatic regulation of adrenal cortical function. Endocrinology 1959, 64, 816.

65. Peterson, R. E. The influence of the thyroid on adrenal cortical function. J. clin. Invest. 1958, 37, 736.

66. Dorfman, R. I. In vivo metabolism of neutral steroid hormones. J. clin. Endocr. 1954, 14, 318.

67. Axelrad, B. J., Cates, J. E., Johnson, B. B., and Luetscher, J. A., Jr. Aldosterone in urine of normal men and of patients with oedema. Its increased recovery after hydrolysis with acid and with beta-glucoronidase. Brit. med. J. 1955, 1, 196.

68. Wolff, H. P., and Koczorek, K. R. Ueber die Ausscheidung von Aldosteron im Harn von Patienten mit Hepatitis Epidemica und Lebercirrhose. Klin. Wschr. 1955, 33, 1104.

69. Dyrenfurth, I., Stacey, C. H., Beck, J. C., and Venning, E. H. Aldosterone excretion in patients with cirrhosis of the liver. Metabolism 1957, 6, 544.

70. Ulick, S., Laragh, J. H., and Lieberman, S. The isolation of a urinary metabolite of aldosterone and its use to measure the rate of secretion of aldosterone by the adrenal cortex in man. Trans. Ass. Amer. Phycns 1958, 71, 225. 